\title{
International Liability for Pollution Damage in Outer Space Environment
}

\author{
OUARDA LAYACHI \\ Department of Law \\ Prince Sultan University \\ P.O. Box 53073 Riyadh 11586 \\ KINGDOM OF SAUDI ARABIA
}

\begin{abstract}
In view of the rapid and dangerous development of space activities and clandestine research, it has become increasingly difficult to identify and determine the environmental damages caused. Jurist of international law have begun to study the international responsibility resulting from such activities, which are leading to the pollution of the outer space environment. States launching space activities launching satellites, and carrying out experiments are introducing harmful substances, terrestrial bacteria, radioactive materials, and harmful space debris that is circling the earth.

This highlights the legal norms of international space law in the area of international liability for damage caused by space activities in the 1967 Outer Space Treaty and the 1972 Convention on Liability for Damage Caused by Space Activities.
\end{abstract}

Key Words: pollution of the outer space environment, International Liability, international space law.

Received: September 13, 2019. Revised: January 25, 2020. Accepted: February 5, 2020.

Published: February 21, 2020.

\section{Introduction}

The environmental pollution of outer space is one of the most serious contemporary international environmental issues. States that launch space activities by introducing any harmful substances, nuclear energy sources or carrying out illegal physical activities such as nuclear explosions or collisions in the outer space environment have or are likely to have consequences. Adverse effects, such as: damage to the Earth and its surroundings; the disruption of space activities, including telecommunications, scientific research and other peaceful activities of other States and impaired validity of legitimate space orbits around the Earth is the focus of this research. International states are free to use and exploit space orbits, in accordance with the principles of international law, the Charter of the United Nations and space law and environmental, terrestrial, oceanic or space orbits, in accordance with the text of Principle II of the 1992 Rio Declaration [1].

\section{The Importance of the Study}

1. The study deals with an important topic, which is polluting the environment of outer space and the means of combating it from a legal perspective.

2. The importance and seriousness of the study is determined by the fact that it does not recognize time limits or spatial limits.
3. This study is one of the most recent studies dealing with mechanisms to combat pollution of the outer space environment.

4. The contribution of this study:

- The identification of national and international legal mechanisms

- The combat plan for the phenomenon of pollution of the outer space environment.

- The possibility of reviewing the procedures and policies taken by various systems and activating the provisions of international treaties and conventions and drafting them in a legislative template to eliminate various crimes of pollution of the outer space environment.

5. It also shows the importance of the practical issue through its findings and recommendations and documented theories and opinions of researchers may benefit specialists and practitioners in this field, as well as sp ecialized agencies in rebuilding a comprehensive strategy to reduce this phenomenon.

\section{Study Objectives}

The research seeks to achieve the main objective of shedding light on the role of legal protection of outer space from environmental pollution by the various uses of outer space, through the following:

- Identify international and national endeavors to determine the concept of pollution of the outer space environment. 
- Detect causes and effects of pollution of the outer space environment by highlighting the concept of scientific experiments or ground bacteria or radioactive materials or space debris.

- Highlight mechanisms that help to reduce nuclear testing and scientific experiments or ground bacteria or radioactive materials or space debris. Through the application of the provisions of international treaties.

- Present recommendations in the light of study results, which promote space protection from scientific experiments or ground bacteria or radioactive materials or space debris, by reference to the application of the provisions of international treaties.

\section{Methodology}

The study of this subject requires the use of the descriptive-analytical approach, which helped us to shed light on the position of national and international legislation and setting strict legal rules against pollution damage, organizing the outer space experiences of countries in a manner that preserves the natural balance of the globe's ocean and its environment.

\section{Search Problem}

Penetration of the human environment of outer space through the exercise of various military and civilian activities requires international attention that sheds light on the dimensions of this human intrusion on space:

What is the concept of environmental pollution of outer space?

How effective are outer space pollution control mechanisms in the light of international laws and treaties?

How effective is the application of general rules of international liability to damage to the pollution of the outer space environment?

Compensation for damage?

\section{International Efforts to Define the Concept of Pollution of the Outer Space Environment}

\subsection{The Definition of the Outer Space Environment}

Scientifically, aerospace is defined as "everything that lies behind the Earth's atmosphere or, in other words, everything that lies 320 kilometers above sea 1 evel" [2]. The space surrounding the globe can be divided into three sections: the atmosphere or outer space, the area between the atmosphere and the moon (Moon), and finally cosmic space (Cosmic Space).

Aerospace consists of several layers, each layer has physical and biological properties that distinguish it from outer space, and these layers include: Troposphere extending at an altitude (10-20 $\mathrm{km}$ ) and above this layer is the stratosphere and up to this layer is very important because it represents the ozone layer (O3), which protects life on Earth from the ultraviolet rays coming from the sun. These rays convert oxygen gas $(\mathrm{O} 2)$ to ozone gas, and consume this process ultraviolet radiation. This layer is in a state of continuous renewal, ozone is inversely converted to oxygen, but oxygen is more ozone due to the energy of ultraviolet radiation [3].

The Mesosphere stretches to an altitude of 80-95 $\mathrm{km}$, in which combustion of meteorites falling from space occurs [4].

The Thermosphere layer extends from the height $(85 \mathrm{~km})$ above and in the upper parts of this layer conversion process begins by X-ray and consists of, in this layer, electron loss in sufficient quantities to make the ionosphere layer reflecting radio waves, created from the ground. These waves are not lost in outer space and are therefore essential for communications in the technological community [5] The last class (Exosphere), starting from a height ranging between $(500-600 \mathrm{~km})$ to $(16000-8000 \mathrm{~km})$, extends and overlaps celestial bodies and then there is outer space [6].

The definition of the outer space environment (The Outer Space Environment) is those places (Regions) surrounding the Earth, where satellites can be taken in its orbit and have a minimum height of almost $100 \mathrm{~km}$.

\subsection{International Efforts to Define the Pollution of the Outer Space Environment}

Definition of pollution of the outer space environment in international instruments.

In fact, a definition of pollution in terms of its contamination of outer space environment in all outer space treaties, as well as in the declarations and decisions of outer space affairs of the United Nations does not exist. In the Outer Space Treaty of 1967, which governs the activities of states in outer space, including the Moon and Other Celestial Bodies, a legal text that defines the intended environmental pollution of outer space does not exist [7] however; there is identification of pollution sources to outer space environment and its causes. It 
is stated in the text of Article IX, the obligation of States parties, that it is necessary to avoid the occurrence of any harmful contamination of outer space, as well as any adverse changes in the ocean of our planet or its environment with non-terrestrial materials. Also banned are experiments of any kind involving weapons on the Moon and Other Celestial Bodies [8].

The sources of pollution of the outer space environment and the reasons set forth in the text of Article IX are activities or experiences that cause harmful pollution of outer space and the changes that damage space objects surrounding the Earth or the Earth itself. Moreover, nuclear weapons and weapons of mass destruction are forbidden and if placed in orbits around the Earth or the moon or any other space this is as crime as contained in the text of Article IV. As well, any parts scattered both above ground (on the territory of another State) or in airspace or outer space from sources of pollution that entails international responsibility [9] are included as outer space and are an object of this treaty. Additionally, the General Assembly recommended in its resolution No. 52/56 of 1997 "to give more attention to all aspects relating to the protection of the outer space environment and conservation, particularly those aspects that have an impact on the Earth's environment" [10].

The Moscow Treaty of 1963 banning nuclear tests in the atmosphere and outer space and under water, it has indicated in its preamble to "put an end to the pollution of the atmosphere and the ocean where human lives". It also announced its primary objective, which is to put an end to the race for or armament production or testing of all types of nuclear weapons, and to stop nuclear weapons testing explosions [11].

Article 1 stipulates that each member of this Agreement shall undertake to prohibit, prevent and not conduct any test of a nuclear weapon or any other nuclear explosion anywhere under his or her authority in outer space.

However, this treaty did not recognize the pollution of the environment, but rather mentioned the causes of pollution resulting from nuclear explosions that cause harmful radioactivity. The United "pollution / pollution", for the purposes of this Instrument, "means human modification of the environment by the introduction of undesirable elements, or by unwanted use of these elements ".

The responsibility for the pollution of the outer space environment and modified ecosystem of outer space is the result of human use and so there must be a legal organization addressing this behavior with the objective to limit the damage to this area. The definition thus must include two pollution factors. First, it is either through the introduction of undesirable elements into this environment, such as nuclear test residues, radiation from nuclear power sources, space objects, remnants or parts after they crash, or any other element of outer space pollution. The increase of such space experiments or objects, in violation of the components of the outer space ecosystem, would also have adverse environmental effects, which would have a negative impact on the future of space activity and would damage the space activities of States at present. The other factor determined by the definition is "The Undesirable Use of Those Elements" in the case of increased launch volume and increased number of satellites which cannot be accommodated by limited-use orbits such as the geostationary orbit.

Outer Space is unable to accommodate spacebased orbits such as the geostationary orbit, increasing them especially after the end of their effectiveness and if not removed or withdrawn to orbits to clear, they will lead to obstruction of space traffic and result in danger and damage in the event of a collision. The undesirable elements are defined in paragraph (b) as "all harmful elements by including space debris".

It should be noted that of all international instruments on outer space issues, this definition is the only mention on pollution and although it is not binding, because it is contained in a draft international document.

It is a good initiative to alert the international community to the urgent need for a legal definition of the pollution of the outer space environment.

The definition contained in the draft did not cover all elements of outer space pollution and its causes, as those causes and elements were linked to a result of, technical development.

\section{How Effective is the Application of General Rules of International Liability to Damage to the Pollution of the Outer Space Environment?}

The International Law Commission has defined international responsibility as "The consequences of any violation of an international obligation" [12] Jurists of international law define international responsibility as "a legal system whereby the State which is charged with the commission of an unlawful act in accordance with international law is obliged to compensate the State which has been injured as a result of such an act" [13] It is clear from this that the basis of international 
responsibility is that the State engages in an unlawful act in accordance with the rules of international law, and that such action would cause harm to another State, obliging the wrongful State to pay compensation [14].

\subsection{The Basis of International Liability Resulting from Damage to Outer Space Pollution}

Traditional international jurisprudence establishes international responsibility based on the theory of error (whether the wrongful act is the result of deliberate action, omission or negligence) [15].

Or on the basis of the theory of unlawful international action (international unlawful action) means $\mathrm{a} b$ reach of an international obligation imposed by a rule of international law, and an international obligation is breached by a State's action or omission. [16].

However, these theories proved incapable of determining the legal basis for such damages, which led to the emergence of the theory of liability or the theory of absolute responsibility. The United Nations has called it the theory of international liability for injurious consequences arising out of acts not prohibited by international law. International liability in this sense is linked to damage.

Originally, space activities are internationally legal, based on the rule of freedom of use of outer space and the freedom of scientific research contained in the text of article I of the Outer Space Treaty of 1967. The limitation on this freedom, however, is the non-pollution of the outer space environment by these activities.

The Convention on I nternational Liability for Damage Caused by Space Objects of 1972 adopted two grounds for establishing liability for damage caused by outer space activities according to the location of the damage [17]:

- If the damage occurred on $t$ he ground, the launching State would ask for absolute liability without any limit of compensation, which was extremely important for the Victim State [18]. Article II of the Convention provides for this responsibility by stating: "The launching State shall have absolute liability for the payment of compensation for damage caused by space objects on the surface of the Earth or aircraft in the event of flight [19].

- If damage occurs in outer space, liability is based on fault, if the damage to the space object or the persons or property it carries, Article III of the
Convention on International Liability for Damage Caused by Space Objects of 1972 states: "If the damage occurs in a place other than the Earth's surface of a space object of a launching State or of persons or funds aboard that space object from the space object of another launching State, the latter State shall be liable, if the damage is due to its error or the fault of the persons responsible for it".

The error of establishing liability for pollution may be proved in the case of as cientific experiment that causes nuclear contamination in outer space or damages the Earth's ocean or environment through observation and traceability provided for in article VI of the Outer Space Treaty.

The error can also be verified under the controls contained in the Declaration of Principles on the Use of Nuclear Power Sources contained in Resolution No. 47/68 of 1992.

As for space debris, its presence in space is associated with legitimate international action, which is a reflection of international law because it is in fact a space object that is supposed to be or transforms into space debris sooner or later.

because damage to another country is done only in the case of collisions with other space ships, or in interference or interference with effective satellite communications from another State, not to mention the use of nuclear power sources.,

In this case, the burden of proving the error lies with the victim party, which is not easy, especially if space debris forms an unidentified piece, which is difficult to verify, and this is a major obstacle [20].

Space debris cannot be identified from the remaining marks on it, and the state that launched the space object cannot be established.

The 1972 Convention on International Liability does not serve the purpose of debris because it only addresses the responsibility of States for errors, and responsibility is no longer universal. The state that made the mistake is the one who is being prosecuted [21].

Thus, in view of the increasing danger associated with the increase in outer space activities, the proof and evidence of the element of error is not an easy matter in the light of the continuing technical developments of space activities, owing to the complexity, confidentiality and ambiguity of their equipment. How can we prove the error of an unknown radioactive debris that has an Earth-orbit orbiting an effective satellite and crashing it? 


\subsection{Conditions of International Liability Resulting from Pollution Damage in the Outer Space Environment}

International responsibility is an obligation imposed by general international law on any person. Public international law compensates an international person who has been injured because of an act or omission [22] from this; we can derive the conditions that must be met to establish international responsibility for space pollution as follows:

\subsubsection{Doing an Action or Refraining from Doing an Act (Conduct)}

In accordance with the general rule, a State bears international responsibility as a result of its actions contrary to international law, whether it is wrong or not, as long as the wrongful act causes damage to another State [23].

With regard to international liability for damage to pollution in the outer space environment as a result of space activity, lawful or unlawful, the undertaking State bore international responsibility as long as it caused damage to another State or space activity of another State.

That is, the State bears responsibility for national activities in outer space that intend to use nuclear power sources, or through damage to other States because of their space object or parts (space debris).

Whether above ground, air or outer space, based on Text of article VI and VII of the Outer Space Treaty and the terms of the Liability Convention [24].

\subsubsection{Damage}

Damage resulting from international responsibility under public international law is defined as "prejudice to the right or legitimate interest of a person of international law". Damage is a condition for the establishment of international responsibility and should therefore be established if it is admissible in accordance with traditional rules of international responsibility [ ].

Damage that can be conceived in outer space by pollution, for example:

-When an inert space object (space debris) is stuck in an orbit of another State.

-When it intercepts frequency beams of a satellite of another State and causes interference or interference in its communications [25].

-With regard to deferred damage, it was specified in the Liability Convention, which provided for an allegation, under which the Claimant State could make a new claim later after the expiration of one year if new facts emerged (Article 10 of the Liability Convention, 1972).
There is atomic damage caused by an atomic space device in outer space, either during its activity or after the expiry of its effectiveness, and there is no dispute in the responsibility of States for atomic damage caused by space activity. However, there are those who believe that atomic damage should be remedied and constituted separately by a special legal instrument, while another believes that the Liability Convention covers all damage that may be caused by space accidents [26].

It should be noted that the damage of nuclear pollution may be delayed period after the collision or explosion due to the non-occurrence of a spaceman and may last for several years.

This is a limitation in the Convention, because the Convention does not protect astronauts in the event of radiation from a space object or debris belonging to another State, when it is outside the spacecraft in outer space or even on a celestial body [27].

Damage to international responsibility must be inflicted on a person by international law. Space damage may be caused to a State or an international organization and impede its space activities. Article eight, in its first paragraph of the Liability Convention, provides for this when it permits the injured State or its natural or legal persons to claim compensation for the damage.

\subsubsection{Ratio of Work to a Person of International Law}

The causal relationship is an essential prerequisite for the establishment of international responsibility. The causal relationship between the harm suffered by another country and the act or refraining from it that the launching country has taken and has resulted in damage to space activity returns to another country.

In the event of such damage, the launching State bears international responsibility for its activities in accordance with the text of Article VI of the Outer Space Treaty, and for the detail provided by the 1972 AD Convention on Liability for Damage Resulting.

Moreover, the term launching state includes in accordance with the text of Article (1) paragraph C From the Liability Agreement:

- The country that launches or manages the launch of the space object.

- The state where the space object is launched from its region or through its facilities.

Accordingly, "The country with the spacecraft can be counted as the launching state, as well as the one that launches the spacecraft on a $\mathrm{m}$ issile that it owns. 
then the country that launches the spacecraft from its territories is also considered in the field of international relations, and in accordance with the relevant rules of general international law, nor It then matters who was the owner of this vehicle or the launcher" [28].

In addition, if two or more countries participate in launching a space object, then these countries are jointly and jointly responsible for any damage they cause, including the damage of environmental pollution in outer space (Article V of the International Liability Convention, 1972).

In the event that an international organization undertakes space activity that causes environmental pollution in outer space, which causes damage to space property, persons or activities of other countries, the responsibility rests with the organization and the States parties to the treaty members of the organization, if the causal relationship exists between the activity and the damage (Article VI of The Outer Space Treaty of 1967, and the text of Article 22, third paragraph of the 1972 International Liability Convention).

In the same regard, the text of the ninth principle came from the Declaration of Principles related to the use of nuclear energy sources in outer space for the year $1992 \mathrm{AD}$, consistent with the text of Article Seven of the Outer Space Treaty and the provisions of the Liability Agreement. It states: "Every country launches or assists in launching a space object, and every country that launches from its province, territory, or facilities the space object is internationally responsible for the damage caused by such space objects, and for its constituent parts, and this would apply entirely." On such an object carrying a nuclear energy vessel on board, and when two or more countries launch a joint launch of such an object, it is subject to international liability for any damage incurred pursuant to the provisions of Article V of the Liability Agreement.

\section{Compensation for Damage}

It is noticed in the provisions of the International Liability Agreement 1972 that it did not specify the amount of compensation, due to the unpredictability of the amount of risk that space activity can cause, and the damage it leads to, as $\mathrm{w}$ ell as that the activity brings benefit to society, and the estimation of compensation in a large and large way hinders such activities Useful, especially in light of the increase in space activities.

The issue of compensation will be dealt with in some detail as follows:

\subsection{Estimate the Compensation}

Article twelve of the 1972 International Liability Agreement stipulates the applicable law to estimate the amount of compensation due to be paid by the launching country, and the goal that must be achieved from the award of compensation [29].

This article stipulated that: "The amount of compensation that the launching State is responsible for paying for damages under this agreement is determined in accordance with international law and the principles of justice and fairness.

So that this compensation leads to the return of the natural or legal person, and the state or international organization, which submits the claim on behalf of from her to the condition that existed before the damage occurred".

We conclude from the text of Article XII of the International Liability Convention, 1972, that in the event of disagreement on the application of the law of a single State.

And to face such a dispute if it occurs, recourse to the rules of international law and the principles of justice and equity, a general principle devised by the text to resolve the dispute that can arise About the law applicable to determine the amount of compensation.

The aim of adopting the rules of general international law, and the principles of justice and equity, appears to be to achieve uniform legal rules applicable to the valuation of compensation.

If the property of persons is damaged by space activities, whether by collision or radiation from the use of nuclear power sources.

Or by damage to humans by interference, interference in communications or other injury from space activities, it shall be subject to the same legal rules governing Compensation, irrespective of the nationality or personality of the injured State, the place of the accident and whether the accident occurred on the ground or in outer space.

It should be noted here that the 1992 Declaration of Principles on the Use of Nuclear Power Sources in Outer Space adopted this text in the assessment of compensation for damage caused by space objects on board nuclear power sources on the basis of the rules of international law and the principles of justice and equity.

It also acknowledged that compensation for radiation damage caused by nuclear power sources carried on board the space object, "Reimbursement of all expenses related to search recovery and clearance operations" (Principle 9-para 3, of the Principles Relevant to the Use of Nuclear Power Sources in Outer Space, Reso. No. 47/68 in 1992). 


\subsection{Regulating the Procedures for Claiming Compensation}

Compensation for damage shall be claimed in accordance with the procedures established by the Convention on International Liability for Damage Caused by Space Activities of 1972, as follows:

\subsubsection{Diplomatic Methods}

The first stage of the procedures for claiming compensation from the launching country begins by diplomatic means.

In the absence of diplomatic relations between the claimant state and the launching state, the first country must request another state to submit its request or assume its interests in accordance with the agreement, but if both the claimant state and the launching state are members of the United Nations, the claim is made through the United Nations (Article 9 of the 1972 Liability Agreement).

\subsubsection{The Claims Committee}

If the diplomatic negotiations did not result in the settlement of the claim within one year from the date of notifying the claiming country of the launching state that it submitted the documents related to its claim, the parties involved create a Claims Resolution Commission, at the request of any of the parties, to resolve related disputes. The Claims Commission is formed of only three members, regardless of the number of claimants participating in the claim or the launching countries. The launching State and the claimant State shall appoint a representative within one year, and the chairman of the committee shall be appointed with the consent of the parties within four months from the date of appointment of the members.

If the President is not chosen, he may be appointed by the Secretary-General of the United Nations (Article 14, A rticle 15, paragraph 1.2, and Article 17 of the International Liability Convention, 1972)

[30].

The main functions of the Claims Commission are:

"To decide on $t$ he subject of the claim for compensation and to determine the amount of compensation payable" provided for in article XVIII of the Liability Convention, in accordance with the rules of general international law and the principles of justice and equity.

This explains that the role of the Claims Commission is not only to indicate the legal rules applicable to international dispute, but also to examine the material facts of the incident to which the provisions of the Convention apply and to determine the necessary compensation.

The Committee shall issue a decision on the award, which shall be binding if agreed upon, but if not agreed, the Committee may issue:

"A final judgment covered by a recommendation accepted by the parties in good faith" (Article 14, Article 15, paragraph 1.2, and Article 17 of the International Liability Convention, 1972). The decision or judgment shall be passed by majority (Article 19, pa ragraph 2, of the International Liability Convention, 1972).

The 1992 Declaration of Principles on the Use of Nuclear Power Sources in Outer Space has been awarded further grants in the settlement of disputes resulting from the damage caused by nuclear energy sources carried on bo ard the space objects in outer space, as stated in the tenth principle:" Any dispute arising from the application of these principles shall be resolved through negotiations or established procedures for the peaceful settlement of disputes in accordance with the United Nations Charter".

The resolution of disputes arising from the application of the principles of nuclear energy sources shall be in accordance with the Charter of the United Nations, and the formulation of the text on such a form is not sufficient, and it should have been explicitly stated on Article (33) of the Charter, especially its first paragraph, to enumerate the means of settling disputes other than negotiations.

Article 33 of the Charter of the United Nations and the Statute of the International Court of Justice stipulate: "The parties to any dispute whose continuation would endanger the maintenance of international peace and security shall seek, first and foremost, a solution by negotiation, investigation, mediation, conciliation, arbitration and judicial settlement, or Regional agencies, organizations or other peaceful means chosen.

\subsubsection{The Deadline to Sue for Compensation}

Article 10 of the Liability Agreement addresses the time limit within which the liability claim is to be filed. It stipulated that the lawsuit should be filed with the launching country during the year following the date of the damage. Also, the time limit may not exceed a period of one year from the date on which it is expected that the state will know the facts by taking the necessary care in a reasonable way (Article Ten (Paragraph 1, 2), Liability Agreement 1972).

However, we believe that the time limitation in the text is an insufficient period for certain types of damages that do not become apparent in a long period, after the space accident, such as $d$ amage 
arising from biological pollution, chemical pollution, and radioactive contamination, and even when the damage is evident it is It is not possible to estimate the full extent of the damage immediately.

As for the damage arising from space debris whose impact extends to very long periods of time that may reach hundreds of years, how will the time period of the damages arising from it be determined?

And if it is possible to determine the date of the damage caused by space debris due to collision with other space objects, interference or interference with satellite communications belonging to another country, then it is not possible to determine the identity of the debris if it is a piece of debris free of any sign, as well as the consequences At the expiry of the time limit period without filing the case, the launching state did not recognize or accept the case.

\section{Conclusion}

The need for international attention to develop a legal regulation addressing issues related to changes in the Earth's environment or pollution of the outer space environment has become an urgent necessity that will determine State responsibility for the damage caused by their prohibited experiments in the outer space environment. Pollution of the outer space environment must be dealt with in an international agreement organized within the framework of the international organization because its risks are too high to be regulated in a treaty, by a treaty (the 1972 Liability Convention).

Based on the above, the international community should agree on mandatory solutions to curb such space experiments and research by enacting strict legal rules against pollution damage.

\section{Recommendations}

Obliging states not to undertake an activity or experiment that will cause any harmful changes in the circumference of the globe when studying and exploring outer space[31].

Prohibition of nuclear explosions even if they are for scientific research or other peaceful purposes.

Setting strict legal rules against pollution damage, organizing the outer space experiences of countries in a m anner that preserves the natural balance of the globe's ocean and its environment.

\section{References:}

[1] Radek Jurcik, Legal and Economic Instruments of Environmental Protection in the Area of Air Protection - Example of Selected Regions of the Czech Republic and Impacts on Entrepreneurs, WSEAS Transactions on Business and Economics, Volume 16, 2019, p. 509, \& Rio Declaration, 1992.

[2] Kanar Mohammed Sami Mustafa: "Atmospheric Components, Characteristics, Effects", unpublished research, Mosul, 2001Mikhail, p. 2.

[3] Saleh Mahdi Al-Obeidi: "Matters of Protection of the Earth's Atmosphere in Contemporary International Law", Journal of Comparative Law, No. 23, 1994, p. 8.

[4] Asaad Abdel Rahim Akrawi: "Ozone Depletion Causes, Potential Results and Treatment Methods", Science Journal, Issue 84, Year 13, March-April 1996, p. 2.

[5] N.H. Langton, 1969, p. 101.

[6] Mikhail Abdul-Ahad: "The Simplified Astronomical Encyclopedia", Mosul, 1st edition, 1977 Moscow Treaty, 1963, p. 234.

[7] Amer Abdul-Fattah Al-Jumard: "The Legal System of Outer Space and the Use of Nuclear Energy", Al-Rafidain Literature Journal, Faculty of Arts, Mosul University, No. 21, 1990, p. 12.

[8] Alawi Amjad Ali: "The legal system of outer space and celestial bodies" Cairo, in 1979, p. 8.

[9] Outer Space Treaty, texts of Articles 4, 7 and 9, 1967.

[10] Daniel Deondi: "Open Space", Foreign Policy Magazine, Research and Information Center, Translation and Military Research Unit, Issue 83, 1984, p. 45.

[11] Iman Naji Abdul Majeed Al-Azzawi: "The Treaty on $t$ he Non-Proliferation of Nuclear Weapons", Master Thesis submitted to the Faculty of Law and Politics, University of Baghdad, 1986, p. 67

[12] Adel Ahmad Al-Taie: "International Responsibility for Internationally Prohibited Acts," Legal Studies, House of Wisdom, Third Issue, Year, 2000, p. 30.

[13] Essam Al-Attiyah: "Public International Law", Baghdad, third edition, 1982, p. 371.

[14] Mohamed Hafez Ghanem: "International Responsibility: A Study of the Provisions of International Law and its Applications of Interest to the Arab Countries", Cairo, 1962, p. 13.

[15] Michel Lascombe, 1996, p. 120. 
[16] Jaber al-Rawi: "The Legal Basis for International Liability for Damage Caused by Environmental Pollution", Journal of Comparative Law, Issue 11, Second Year, 1980 , p. 75.

[17] Mahmoud Hijazi Mahmoud: "International Responsibility for Damage Caused by Space Objects", Helwan University, 2003, p. 69.

[18] Suha Humaid Salim Al-Jumaa: "Pollution of the Outer Space Environment in Public International Law", Alexandria, University Press, 2009, p.67.

[19] Convention on I nternational Liability for Damage Caused by Space Objects, 1972.

[20] Ben Hamouda Leila: "International Responsibility in Space Law", Algeria, Dar Houma, 2009, p. 87.

[21] 35-Pierre-Marie Dupuy: "Public International Law", Paris, 2000, p. 675.

[22] Mohammed Bahiuddin Arjun: "Outer Space and its Peaceful Uses", Kuwait, World of Knowledge, 2006, p. 89.

[23] Ben Hamouda Leila: "Peaceful Use of Outer Space", Beirut, University Foundation for Studies, Publishing and Distribution, First Edition, 2008, p.98.

[24] Messaoud Menteri: "International Responsibility of States for Damage to Extra Atmospheric Space, R.A.S.J.E.P. - No. 3, September 1987, p. 35.

[25] 18-Laurence Ravillon: "extra-atmospheric space (commercial exploitation), jurusclasseur international law, united Burgundy, France, 9/6/2009, p. 23.

[26] Sarah Estabrooks:" space security", Conference Report (UNIDIR), 2006, p. 35.

[27] Vladimir Kopal: "On the Principles Governing State Activities in the Exploration and Use of the Outer Space of the Moon and Other Celestial Bodies", United Nations Audiovisual Library of International Law, 2008, www.un.org/law/avl, p. 46.

[28] Leonard David:" space debris a growing challenge", The American institute of aeronautics and astronautics, October 2009, p. 56.

[29] Christian Brunner, Alexander Soucek:" Outer space in society, politics, and law space", Germany, springer, 2011, p. 41.

[30] Article 14, Article 15, paragraph 1.2, a nd Article 17 of the International Liability Convention, 1972.

[31] Aram Hanna Massoudi, Sahar Jalal Fatah, Mohamed Essam Ahmed
Incorporating Green Innovation to Enhance Environmental Sustainability, WSEAS Transactions on Business and Economics, Volume 16, 2019, p. 486 